\title{
Crop Water Requirement and Crop Coefficient of Tef (Eragrostis tef) in Central Rift Valley of Ethiopia
}

\author{
Tilahun Hordofa Gobena Dirirsa Tatek Wondimu Abera Tesfaye Ketema Tezera \\ Melkassa ARC, PO Box 436, Adama, Ethiopia.
}

\begin{abstract}
Tef is the most important native cereal crop to Ethiopia and widely grown under rain-fed agriculture. Irrigation is essential in arid and semi-arid areas where rainfall is unreliable and insufficient for crop production. Rational application of irrigation water is based on the knowledge of crop water requirement. Field study was undertaken at the experimental farm of Melkassa agricultural research center located in the central rift valley of Ethiopia. Nonweighing lysimeter was used to measure daily crop water requirement of tef grown on a clay loam soil. The reference evapotranspiration was determined from daily climatic data using Penman-Monteith method and Kc was obtained from the ratio of measured crop water requirement as obtained from water balance equation to estimated reference evapotranspiration. The measured crop water requirement values tef during growth stages of initial, development, mid-season and late season were $36.4 \mathrm{~mm}, 109.9 \mathrm{~mm}, 166.5 \mathrm{~mm}$, and $50.9 \mathrm{~mm}$, respectively. The corresponding Kc-values as a fraction during growth stages were $0.46,0.88,1.03$ and 0.57 . Fifth-order polynomials function was found to fit well to predict the crop coefficient values as functions of days after sowing that can be applicable in similar agro-climatic region for irrigation design and water management practices.
\end{abstract}

Keywords: Crop water requirement, reference evapotranspiration, Kc, drainage lysimeter, tef

DOI: $10.7176 / J N S R / 11-15-04$

Publication date:August $31^{\text {st }} 2020$

\section{Introduction}

Tef (Eragrostis tef) is the most important native cereal crops grown in Ethiopia and ranks first in cultivated area among all annual crops. The crop is predominantly produced as a staple food for local consumption and an important cash crop for farm households. It is produced solely under rain fed conditions during mid-July to early August, usually when the soil water is assumed to reach near field capacity (Steduto et al, 2012).

Water scarcity is the major limiting factor for tef production and productivity mostly in arid and semi-arid regions of the country. Rainfall in the regions is unreliable and insufficient for crop production. A research finding shows that tef benefits from supplementary irrigation in locations prone to terminal drought (Araya et al., 2010). Irrigation water is a vital input for maximizing crop production and a rational application of irrigation water is based on the knowledge crop water requirement which is defined as the amount of water required to compensate the crop evapotranspiration, ETc loss from the cropped field. The ETc varies considerably during the growing period due to variation in crop canopy and climate conditions (Allen et al., 1998). Accurate estimation of ETc is essential for proper water resource planning, irrigation project planning and irrigation water management practices.

An important element in the estimation of ETc is the reference evapotranspiration, ETo. Various methods were developed (Hargreaves and Samani, 1985; Doorenbos and Pruitt, 1977; Makkink, 1957 and Thornthwaite and Holzman, 1942) to estimate ETo and FAO Penman-Monteith estimation method is recommended as the sole standard method correctly predicting ETo in a wide range of locations and climates (Allen et al., 1998).

The ETc can be determined from isolated crop root zone grown inside a lysimeter. The method permits to monitor the incoming and outgoing water flux into and from the crop root zone, respectively over growing periods. The Kc is a crop coefficient and serves as an aggregation of the physical and physiological differences between crops (Allen et al. 1998).

Locally determined Kc-values were not available for many crops in Ethiopia and values suggested by FAO (Allen et al., 1998) are most commonly used to estimate ETc. Yenesew (2015) and Solomon (2010) studied the ETc and Kc-values for tef in semi-arid areas during dry season. Nevertheless, no information on the water requirement and crop coefficient values were available for the wet season. Doorenbos and Pruitt (1977) emphasized the strong need for locally calibrated Kc-values under given climatic conditions. Hence, lysimeter based study was undertaken to find out seasonal ETc and Kc-values of tef at different growth stage under semiarid climatic condition of Melkassa, Ethiopia.

\section{Materials and Methods}

2.1 Study area

The study was conducted at Melkassa Agricultural Research Center. The center is located in the Central Rift Valley of Ethiopia $\left(8^{\circ} 24^{\prime} \mathrm{N}\right.$ latitude and $39^{\circ} 21^{\prime} \mathrm{E}$ longitude with altitude of 1,550 masl). The climate of the area is characterized as semi-arid with low and erratic rainfall pattern. The long-term climatic data $(1977-2018)$ indicate annual average of $825 \mathrm{~mm}$ and about $67 \%$ of the total rainfall of the area occurs from June to September. The 
mean maximum and minimum temperatures were $28.7^{\circ} \mathrm{C}$ and $13.8^{\circ} \mathrm{C}$, respectively. The soil texture in the study area was clay loam with bulk density of $1.11 \mathrm{gm} / \mathrm{cm} 3$. Field capacity (FC) and permanent wilting point (PWP) of the soil were $34.6 \%$ and $17.6 \%$, respectively.

\subsection{The Experimental setup}

Two non-weighing lysimeters of $2 \mathrm{~m} 2(2 \times 1)$ and $4 \mathrm{~m} 2(2 \times 2)$ area and $1 \mathrm{~m}$ depth were used for this experiment. Each lysimeter has an access chamber for aeration and underground steel pipes connected to drain chamber for collecting excess water. The rim of each lysimeter protrudes $10 \mathrm{~cm}$ above the soil surface to avoid surface water run-on and runoff that may happen during the rain occurrence. Access tubes were installed at the center of each lysimeter down to $100 \mathrm{~cm}$ depth to monitor the soil moisture inside the lysimeter.

\subsection{Tef agronomy}

Tef (Gemechis cultivar) was sown in late July on carefully prepared inside and outside the lysimeter to maintain a similar environment. Irrigation water was applied when $50 \%$ of the total available water depleted within the root depth inside and outside the lysimeters during the growing season to bring the soil moisture to field capacity. Allen et al. (1998) indicated the allowable depletion fraction for all cereals as 0.55 and pointed out that for hot dry weather conditions, where ETc is high, the depletion fraction is $10-25 \%$ less than the value indicated. All other cultural practices other than irrigation for the outside and inside the lysimeters were same recommended for the area. Irrigation was terminated when the crop show sign of maturity and harvested in the late October during the three successive experimental period.

\subsection{Soil moisture measurement and irrigation application}

Soil moisture was measured using calibrated neutron probe for the lower soil depths $(15-30,30-45,45-60,60-75$ and $75-90 \mathrm{~cm}$ ) and gravimetric method was used for the upper soil depth of $0-15 \mathrm{~cm}$ during the growth period. The amount of irrigation was dependent on the growth stage of the crop, weather, and rooting depth. Measured amount of irrigation was applied to the crop using graduated buckets.

\subsection{Determination of crop evapotranspiration}

The tef ETc for each growth stage was obtained from the following soil water balance equation.

$$
E T c=I+R-D-\Delta S
$$

Where, ETc is evapotranspiration of the crop $(\mathrm{mm}), \mathrm{I}$ is depth irrigation $(\mathrm{mm}), \mathrm{R}$ is rainfall $(\mathrm{mm}), \mathrm{D}$ is drainage water $(\mathrm{mm})$, and $\Delta \mathrm{S}$ is change in storage of soil moisture $(\mathrm{mm})$.

Daily amount of rainfall was obtained from the meteorological observatory located near the experimental plots. Deep percolation was observed daily that may occur from rainfall events in excess above and measured with the help of graduated cylinder at drainage collection chamber.

\subsection{Determination of reference crop evapotranspiration}

Daily metrological data such as minimum and maximum temperatures, sunshine hours, wind speed and relative humidity were collected from Melkassa agricultural research center's meteorological observatory. Daily ETo was computed from FAO Penman-Monteith method using cropwpat8.0 model (Allen et al. 1998). The Kc-values for the different growth stages were obtained from the following relationship.

$$
\mathrm{Kc}=\mathrm{ETc} / \mathrm{ETo}
$$

Where, Kc is crop coefficient (fraction); ETc is crop evapotranspiration ( $\mathrm{mm} / \mathrm{day}$ ), and ETo is reference evapotranspiration ( $\mathrm{mm} /$ day).

\section{Results and discussion}

\subsection{Crop water requirement}

The result for the water balance component as obtained from the lysimeter and daily ETo as computed from climatic data is presented (Table 1). The crop water requirement of tef was low at the initial stage and increased during the development stage reaching maximum value of $5.04 \mathrm{~mm}$ day-1at mid-season stage, and thereafter declined during late-season stage. The difference in ETc is attributed to the combined effects of development of crop, changes in evaporative demand of the atmosphere and difference in energy-absorption characteristics. The increase in ETc during the development stages can be explained by change in evaporative demand and rapid crop growth. The reduction in ETc in the late stage was due to the physiological deterioration of foliage as a result of translocation of photosynthesis from leaves to seeds, which reduced crop transpiration and the termination of irrigation. The water balance components of tef, reference evapotranspiration and Kc-values over years are presented ((Table 1.1 to 1.3$)$.

The growth stages of tef under Melkassa climatic condition could take 15, 25, 35 and 15 days during initial, crop development, midseason and late season growth stages, respectively (Table 1.1 to 1.3). And hence, tef cultivar 
Gemechis could take about 90 days to mature under Melkassa climatic condition. The average seasonal crop water requirement of tef ranged between 346 to $378.4 \mathrm{~mm}$ and the Kc-values during initial, crop development, midseason and late season growth stages were $0.46,0.88,1.02$ and 0.57 , respectively.

FAO (2012) reported that seasonal ETc of early maturing tef estimated using AquaCrop or other simulation models for Ethiopian highlands would fall in the range of 280 to $300 \mathrm{~mm}$. According to NARC (1996), many cultivars require 200 to $300 \mathrm{~mm}$ of water during early growth period. Seyfu (1997) reported that 300 to $500 \mathrm{~mm}$ of rainfall is adequate in a growing season and even less than $300 \mathrm{~mm}$ seasonal rainfall may be sufficient for earlymaturing cultivars.

\subsection{Crop coefficient}

The computed Kc for tef is presented in Table 3.Crop coefficient curve for average values over year is indicated in Fig. 1. It can be observed that there was a consistent rise from 0.46 to 1.03 and a decrease to 0.57 . The midseason stage runs from effective full cover to the start of maturity. The beginning of late season has been indicated by yellowing or senescence of leaves, to the degree that the crop evapotranspiration is reduced relative to the reference ETo. Senescence is usually associated with less efficient stomata conductance of leaf surfaces due to the effects of ageing, thereby restricting transpiration and causing a reduction in crop coefficient. Factors affecting the value of the crop coefficient $(\mathrm{Kc})$ are mainly the crop characteristics, sowing date, rate of crop development, length of growing season, soil evaporation and climate (Doorenbos and Pruitt 1977).

Crop coefficient values initially increased rapidly, since the soil surface was wetted byirrigation and/ or rainfall, so that the amount of water available in the topsoil for evaporation was considerable. Allen et al. (1998) reported that the Kc during the initial period is large when the soil is wet from irrigation and rainfall and is low when the soil surface is dry. Subsequently, the evolution of Kc values reflected the effects of crop growth, development and physiology on ETc. The increase in Kc value during the development and mid-season stages is due to the rapid crop development. As the crop develops and shades the ground to the effective full cover and reach full size, the amount of water abstraction increased which in turn increased the ETc. A maximum Kc value (1.13) was obtained during the mid-season, when ETc reached its highest demand.

The average Kc values during initial, mid-season and end of late season stages were $0.46,1.03$ and 0.57 respectively ((Table 3$)$.

\subsection{Crop coefficient and days after sowing (DAS)}

Regression analysis developed between Kc-vales and day after sowing, DAS gave fifth-order polynomial equation withhigh coefficient of determination, $\mathrm{r} 2=0.92$ (Fig. 1). The relationship developed will help to predict Kc-values under similar climatic condition of Melkassa that eventually used for most applications related to irrigation planning, design and agricultural water management practices.

$$
\begin{gathered}
\mathrm{Kc}=-2 \mathrm{E}-09 \mathrm{DAS}{ }^{5}+5 \mathrm{E}-07 \mathrm{DAS}^{4}-5 \mathrm{E}-05 \mathrm{DAS}^{3}+0.0022 \mathrm{DAS}^{2}-0.0165 \mathrm{DAS}+0.4293 \\
\mathrm{R}^{2}=0.92
\end{gathered}
$$

Different scholars (Yenesew, 2015; Hanson and May 2006 and Kang et al., 2003) developed a multiple regression analysis for predicting Kc-values under a specific local condition. Kang et al. (2003) proposed a fifth order polynomial equation for wheat and maize with a high coefficient of determination, $\mathrm{r} 2=0.96$.

\section{References}

Allen, R. G., L.S. Pereira, D. Raes and M. Smith. (1998). Crop evapotranspiration. Guidelines for computing crop water requirements. FAO Irrigation Drainage Paper No. 56. FAO, Rome, Italy

Araya, A., , S.D.Keesstra and L. Stroosnijder. (2010). Simulating yield response to water of tef (Eragrostis tef) with FAO's AquaCropmodel. Field Crops Research 116:196-204.

Doorenbos, J. and W. O. Pruitt. (1977). Guidelines for predicting crop water requirements. FAO Irrigation Drainage Paper No. 24. FAO, Rome, Italy.

FAO (Food and Agricultural Organization). (2012). Crop yield response to water. FAO Irrigation Drainage Paper No. 66. FAO, Rome, Italy.

Hanson, B.R. and D. M. May. (2006). New crop coefficient developed for high-yield processing tomatoes. Calif Agric, 60(2):95-99

Hargreaves, G.H. and Z.A. Samani.(1985). Reference crop evapotranspiration from temperature. ASAE. Trans.1 (2):96-99.

Kang, S., B. Gu, T. Du, and J. Zhang. (2003). Crop coefficient and ratio of transpiration to evapotranspiration of winter wheat and maize in a semi-humid region: Agricultural water management, 59 (3):239-254.

Makkink, G.F. (1957). Testing the Penman formula by means of lysimeters. J Inst. Water Eng. 11(3):277-278.

NRC (National Research Council). (1996). Lost crops of Africa. Volume I: Grains. National Academy Press Washington, DC, USA.

Seyfu, ketema.(1997). Tef. Eragrostis tef (Zucc.) Trotter.Promoting the conservation and use of under utilized and 
neglected crops. Institute of Plant Genetics and Crop plant Research Institute, Rome, Italy

Solomon Jemal. (2010). Impact of Climate Variability on Water Productivity and Yield of tef (Eragrostis tef) in Central Rift Valley, Ethiopia.MSc thesis. Agronomy. Haramaya University, Haramaya, Ethiopia.

Steduto, P., T.C. Hsiao, E. Fereres and D. Raes. (2012). Crop yield response to water. FAO irrigation and drainage paper No. 66. FAO, Rome, Italy.

Thornthwaite, C.W. and B. Holzman. (1942). Measurement of evaporation from land and water surface. USDA Tech. Bull. 817, 143p.

Yenesew Mengiste, 2015. Agricultural Water Productivity Optimization for Irrigated Teff (Eragrostic Tef) in Water Scarce Semi-Arid Region of Ethiopia.PhD dissertation.Wageningen University. Water resource management.CRC Press/Balkema. The Netherlands.

Table 1.1 Water balance components for tef under Melkassa climatic condition during 2015 cropping season

\begin{tabular}{|l|l|l|l|l|l|l|l|}
\hline DAS & $\begin{array}{l}\text { Irrigation } \\
(\mathrm{mm})\end{array}$ & $\begin{array}{l}\text { Rain } \\
(\mathrm{mm})\end{array}$ & Drainage $(\mathrm{mm})$ & $\begin{array}{l}\text { ETc } \\
(\mathrm{mm})\end{array}$ & $\begin{array}{l}\text { ETc } \\
(\mathrm{mm} / \text { day })\end{array}$ & $\begin{array}{l}\text { ETo } \\
(\mathrm{mm} / \text { day })\end{array}$ & Kc \\
\hline $01-03$ & 16.00 & 11.63 & 6.54 & 5.08 & 1.69 & 5.46 & 0.31 \\
\hline $04-06$ & - & 6.00 & 10.43 & 5.55 & 1.85 & 5.60 & 0.33 \\
\hline $07-09$ & - & 0.00 & - & 6.56 & 2.19 & 6.25 & 0.35 \\
\hline $10-13$ & - & 13.20 & 4.01 & 8.08 & 2.02 & 5.18 & 0.39 \\
\hline $14-17$ & - & 0.00 & - & 8.17 & 2.04 & 4.75 & 0.43 \\
\hline $18-21$ & - & 1.35 & - & 12.67 & 3.17 & 5.66 & 0.56 \\
\hline $22-25$ & 19.35 & 11.10 & 1.10 & 15.49 & 3.87 & 5.38 & 0.72 \\
\hline $26-30$ & 11.49 & 2.40 & 0.00 & 22.03 & 4.41 & 5.25 & 0.84 \\
\hline $31-39$ & 19.63 & 43.88 & 16.84 & 48.17 & 5.35 & 5.58 & 0.96 \\
\hline $40-44$ & 21.19 & 1.88 & - & 24.81 & 4.96 & 4.91 & 1.01 \\
\hline $45-50$ & - & 20.25 & - & 31.50 & 5.25 & 5.10 & 1.03 \\
\hline $51-57$ & 34.18 & 13.58 & - & 31.54 & 4.73 & 4.59 & 1.03 \\
\hline $58-64$ & - & 12.60 & - & 35.74 & 5.11 & 5.21 & 0.98 \\
\hline $65-69$ & 41.10 & 1.88 & - & 24.82 & 4.96 & 5.28 & 0.94 \\
\hline $70-74$ & 22.94 & 0.00 & - & 25.85 & 5.17 & 5.68 & 0.91 \\
\hline $75-79$ & 25.85 & 0.00 & - & 24.07 & 4.81 & 5.87 & 0.82 \\
\hline $80-85$ & 24.07 & 0.00 & - & 24.00 & 4.00 & 5.88 & 0.68 \\
\hline $86-93$ & 24.00 & 6.15 & - & 22.69 & 2.84 & 6.17 & 0.46 \\
\hline Total & 259.81 & 145.88 & 38.92 & 376.82 & & & \\
\hline DAS Day & -19 & $\mathrm{n}$ & & & & \\
\hline
\end{tabular}

DAS ${ }^{*}$ Days after sowing, I=Irrigation, $\mathrm{R}=$ Rainfall, $\mathrm{D}=$ Drainage, ETc=Crop Evapotranspiration, ETo=Reference Evapotranspiration, $\mathrm{Kc}=$ Crop Coefficient

Table 1.2 Water balance components for tef under Melkassa climatic condition during 2017 cropping season

\begin{tabular}{|c|c|c|c|c|c|c|c|}
\hline DAS & $\begin{array}{l}\text { Irrigation } \\
(\mathrm{mm})\end{array}$ & $\begin{array}{l}\text { Rain } \\
(\mathrm{mm})\end{array}$ & Drainage $(\mathrm{mm})$ & $\begin{array}{l}\text { ETc } \\
(\mathrm{mm})\end{array}$ & $\begin{array}{l}\text { ETc } \\
(\mathrm{mm} / \text { day })\end{array}$ & $\begin{array}{l}\text { ETo } \\
(\mathrm{mm} / \text { day })\end{array}$ & $\mathrm{Kc}$ \\
\hline $01-03$ & 16.2 & 70.8 & 63.5 & 7.3 & 1.8 & 4.0 & 0.46 \\
\hline 04-08 & - & 17.8 & 9.2 & 10.1 & 2.0 & 3.9 & 0.52 \\
\hline 09-14 & - & 10.6 & - & 12.5 & 2.5 & 4.4 & 0.57 \\
\hline $15-18$ & - & 9.5 & - & 16.0 & 3.2 & 4.5 & 0.71 \\
\hline $19-22$ & - & 10.6 & - & 14.6 & 3.6 & 4.5 & 0.81 \\
\hline $23-29$ & - & 43.3 & 3.6 & 25.9 & 3.7 & 3.9 & 0.94 \\
\hline $30-31$ & - & 18.4 & 9.8 & 8.6 & 4.3 & 4.4 & 0.97 \\
\hline $32-33$ & - & 9.3 & - & 10.1 & 5.0 & 5.0 & 1.00 \\
\hline 34-39 & - & 39.8 & 21.3 & 32.5 & 5.4 & 4.8 & 1.13 \\
\hline $40-43$ & - & 19.5 & - & 19.7 & 4.9 & 4.3 & 1.14 \\
\hline
\end{tabular}




\begin{tabular}{|l|l|l|l|l|l|l|l|}
\hline DAS & $\begin{array}{l}\text { Irrigation } \\
(\mathrm{mm})\end{array}$ & $\begin{array}{l}\text { Rain } \\
(\mathrm{mm})\end{array}$ & Drainage $(\mathrm{mm})$ & $\begin{array}{l}\text { ETc } \\
(\mathrm{mm})\end{array}$ & $\begin{array}{l}\text { ETc } \\
(\mathrm{mm} / \text { day })\end{array}$ & $\begin{array}{l}\text { ETo } \\
(\mathrm{mm} / \text { day })\end{array}$ & Kc \\
\hline $44-45$ & - & 12.2 & - & 8.5 & 4.3 & 3.6 & 1.17 \\
\hline $46-51$ & 22.1 & 34.0 & 14.4 & 30.4 & 5.1 & 4.4 & 1.16 \\
\hline $52-60$ & 25.6 & 20.3 & - & 45.9 & 5.1 & 4.5 & 1.14 \\
\hline $61-64$ & - & 0.0 & - & 23.0 & 5.8 & 5.2 & 1.11 \\
\hline $65-69$ & 34.3 & 4.5 & - & 27.0 & 5.4 & 5.2 & 1.03 \\
\hline $70-79$ & 35.6 & - & - & 35.6 & 3.6 & 5.3 & 0.67 \\
\hline $80-86$ & - & - & - & 18.4 & 2.6 & 5.6 & 0.47 \\
\hline Total & 133.8 & 320.6 & 121.7 & 346.0 & & & \\
\hline
\end{tabular}

Table 1.3 Water balance components for tef under Melkassa climatic condition during 2018 cropping season

\begin{tabular}{|c|c|c|c|c|c|c|c|}
\hline DAS & $\begin{array}{l}\text { Irrigation } \\
(\mathrm{mm})\end{array}$ & $\begin{array}{l}\text { Rain } \\
(\mathrm{mm})\end{array}$ & Drainage $(\mathrm{mm})$ & $\begin{array}{l}\text { ETc } \\
(\mathrm{mm})\end{array}$ & $\begin{array}{l}\text { ETc } \\
(\mathrm{mm} / \text { day })\end{array}$ & $\begin{array}{l}\text { ETo } \\
(\mathrm{mm} / \text { day })\end{array}$ & $\mathrm{Kc}$ \\
\hline $01-04$ & - & 31.1 & 10.0 & 7.9 & 2.0 & 4.39 & 0.45 \\
\hline 05-08 & - & 21.5 & 25.2 & 8.2 & 2.1 & 4.38 & 0.47 \\
\hline $09-12$ & - & 1.6 & - & 9.5 & 2.4 & 4.64 & 0.51 \\
\hline $13-16$ & - & 9.0 & - & 10.9 & 2.7 & 5.07 & 0.54 \\
\hline $17-20$ & 13.50 & 33.4 & 24.1 & 9.3 & 2.3 & 4.17 & 0.56 \\
\hline $21-23$ & - & 5.6 & 2.2 & 9.6 & 3.2 & 4.92 & 0.65 \\
\hline $24-27$ & - & 5.1 & - & 13.6 & 3.4 & 4.37 & 0.78 \\
\hline $28-31$ & 14.74 & 0.0 & - & 15.6 & 3.9 & 4.65 & 0.84 \\
\hline $32-36$ & - & 11.1 & - & 21.0 & 4.2 & 4.58 & 0.92 \\
\hline $37-41$ & - & 29.2 & - & 22.0 & 4.4 & 4.47 & 0.98 \\
\hline $42-46$ & - & 57.2 & 25.3 & 17.2 & 3.4 & 3.33 & 1.03 \\
\hline $47-51$ & - & 10.7 & 7.5 & 22.0 & 4.4 & 4.27 & 1.03 \\
\hline $52-55$ & 14.89 & - & 25.2 & 20.4 & 5.1 & 4.91 & 1.04 \\
\hline $56-59$ & 20.43 & 5.3 & - & 18.4 & 4.6 & 4.49 & 1.03 \\
\hline $60-63$ & - & 16.9 & - & 17.6 & 4.4 & 4.31 & 1.02 \\
\hline 64-66 & - & 3.6 & 24.1 & 15.3 & 5.1 & 4.94 & 1.03 \\
\hline $67-70$ & 25.58 & 5.4 & 2.2 & 20.4 & 5.1 & 5.07 & 1.01 \\
\hline $71-75$ & 15.24 & - & - & 28.0 & 5.6 & 5.66 & 0.99 \\
\hline $76-80$ & 28.01 & 0.2 & - & 27.8 & 5.6 & 5.84 & 0.95 \\
\hline $81-85$ & 27.61 & - & - & 22.2 & 4.4 & 5.77 & 0.77 \\
\hline $86-90$ & 22.22 & - & - & 17.4 & 3.5 & 6.01 & 0.58 \\
\hline $91-96$ & - & - & - & 12.2 & 2.0 & 5.08 & 0.40 \\
\hline Total & 182.22 & 246.53 & 84.32 & 366.58 & & & \\
\hline
\end{tabular}


Table 1. Stage-wise tef ETc over years and mean ETo

\begin{tabular}{|l|l|l|l|l|l|}
\hline \multirow{2}{*}{ Cropping season } & \multicolumn{5}{|c|}{ Stage-wise ETc(mm) } \\
\cline { 2 - 6 } & Initial & Development & Mid-season & Late season & $\begin{array}{l}\text { Total growing } \\
\text { period }\end{array}$ \\
\hline Year - I & 33.44 & 123.18 & 175.09 & 46.69 & 378.40 \\
\hline Year - II & 29.92 & 107.56 & 154.54 & 54.03 & 346.05 \\
\hline Year - III & 45.88 & 98.99 & 169.86 & 51.86 & 366.58 \\
\hline Average ETc \pm & 36.41 & 109.91 & 166.50 & 50.86 & 363.68 \\
STDEV & \pm 6.85 & \pm 10.01 & \pm 8.72 & \pm 3.08 & \pm 13.36 \\
\hline ETo(mm) & 79.83 & 124.52 & 163.37 & 88.78 & 456.50 \\
\hline Average Kc & 0.46 & 0.88 & 1.02 & 0.57 & 0.80 \\
\hline
\end{tabular}

Table 2. Stage-wise crop coefficient values for tef under Melkassa climatic condition

\begin{tabular}{|c|c|c|c|}
\hline Lysimeter & \multicolumn{3}{|c|}{ Stage-wise crop coefficient $\left(\mathrm{K}_{\mathfrak{c}}\right)$} \\
\hline & Initial & Mid-season & End of season \\
\hline Year -1 & 0.36 & 0.95 & 0.57 \\
\hline Year -2 & 0.52 & 1.13 & 0.57 \\
\hline Year-3 -1.01 & 1.01 & 0.58 \\
\hline Average Kc & 0.51 & 1.03 & 0.57 \\
\hline
\end{tabular}

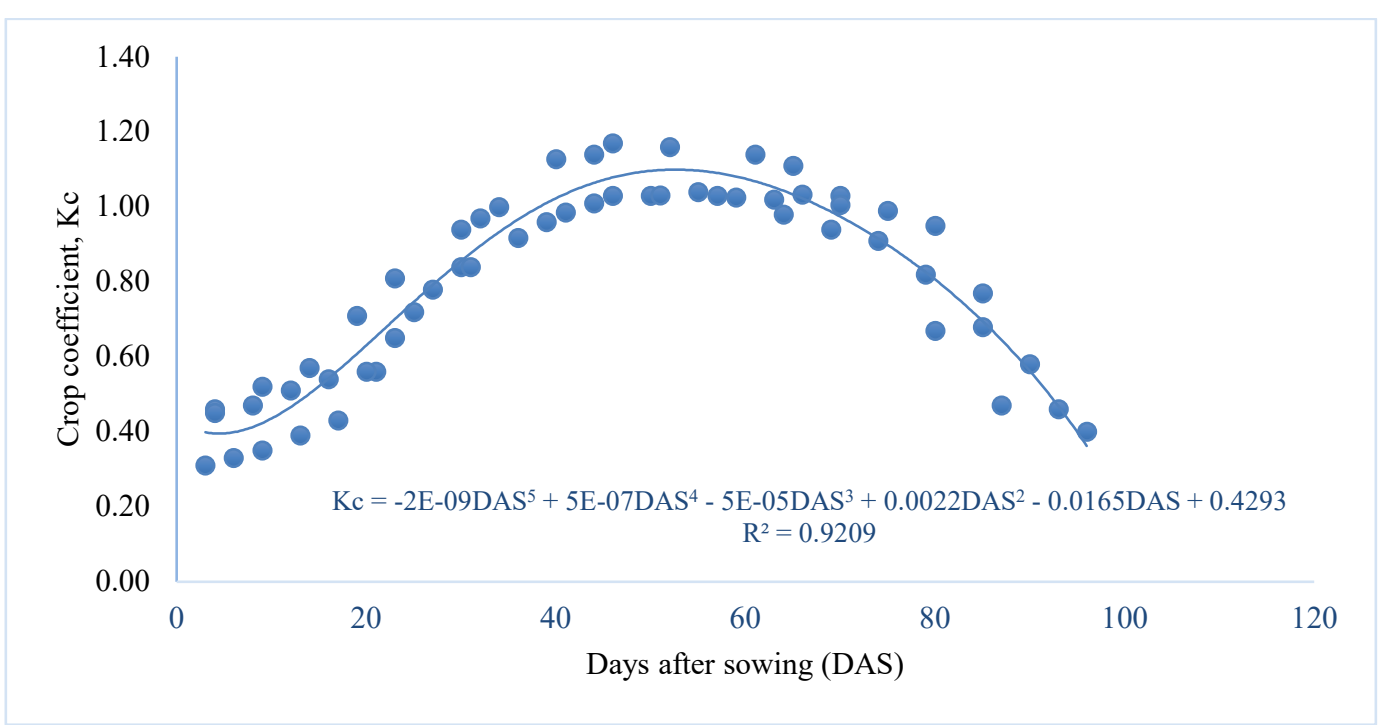

Figure 1.Relationship between observed Kc-values and days after sowing for tef 